\title{
EXPERIENCES ON LICENSED OFFICES OF SURVEYING AND CADASTRE (LOSC) IN ADANA, TURKEY
}

\author{
G.Yalcin ${ }^{\mathrm{a},},{ }^{1}$ H.B. Ates ${ }^{\mathrm{b}}$ \\ ${ }^{a}$ Korkut Ata University, Dept. of Geomatic Engineering, Osmaniye, guleryalcin@ osmaniye.edu.tr \\ ${ }^{\mathrm{b}}$ Adana-Sarıçam Licensed Office of Surveying and Cadastre, Adana, bahadirates@yandex.com
}

KEY WORDS: Surveying, Cadastre, Licensed Office, Adana

\begin{abstract}
:
Modern cadastre means to integrate the registration of the real estates with the data of the other related activities such as taxation, mortgage, valuation, land-use, land cover,..etc. In Turkey cadastral technical activities were carried out by General Directorate of Land Registry and Cadastre until 2005. But then cadastre sustainment services were transferred to private sector according to "Law on Cadastre" technical parts of initial cadastre and according to the Law on "Licensed Engineers of Surveying and Cadastre and Offices". In this article services of Licensed Offices of Surveying and Cadastre (LOSCs) are presented and the experiences in Adana are shared.
\end{abstract}

${ }^{*}$ Corresponding author 


\section{INTRODUCTION}

In Turkey "title registration system" is used as cadastral services. Cadastral surveys are based on "3402 Cadastre Law" which was entered into force in 1987. General Directorate of Land Registry and Cadastre (GDLRC) is responsible for carrying out the cadastral services with its 22 Regional Directorates (RD) countrywide. These regions are also divided into 81 Cadastre Directorates (CD). The cadastre directorates perform only surveying related services as 970 Land Registry Directorates (LRD) are responsible for land registry records of property rights. All directorates report to their Regional Directorates and also RD report to GDLRC (TKGM, 2016a). Cadastre Directorates perform cadastral technical services such as services on initial cadastre, sustainment of cadastre and nonregistered services under the body of GDLRC. "Initial cadastre" is the survey and registration of real estate and its rights in a predetermined area for the first time. "Sustainment cadastre" is the renovation and update of the cadastral information and documents that change in time such as subdivision of parcels, consolidation of parcels, development plan implementations, establishment or abolishment of easements, changes of land-use type, renovation of cadastre (Konbul and Cete, 2015).

In cadastral on-demand technical services, to present a copy of a real estate on the map (plan example), to show a real estate on the field, to prepare a sketch depending on the field measurement with the use of measurement values and parcel boundary points and control points of a real estate (application), to determine the position of a building to be constructed, to produce title plans, to provide technical information are named as "transactions not subject to the registration" or non-registered services". On the other hand change on land-use type, establishment or abolishment of easements, parcel consolidations are named as "transactions subject to the registration" or "registered services" (Implementation Regulation of Law on Licensed Engineers of Surveying and Cadastre and Offices, 2016).

Due to the fact that cadastral technical services have grown in volume, it is mandatory to provide these services by private sectors. Also it is aimed to create new employment areas by establishing offices and to run cadastral services effectively and fast by assigning public personnel who are competent on cadastral services (Aykit et al., 2015). GDLRC started to transfer some parts of increasing demand on cadastral services to private sector with the reinforcement of change of Article 3 in Law on Cadastre numbered 3402 in 2005. Then Licensed Offices of Surveying and Cadastre (LOSC) (LIHKAB in Turkish) were established with Law on LOSC numbered 5368 in 2005. This law aims to determine the principles and procedures on activities, controls and responsibilities of the licensed surveying and cadastre engineers, and also offices to be established.

In past, all kinds of cadastral services were done by personnel of GDLRC. Then technical parts of initial cadastre according to (Law on Cadastre, 1987) and cadastre sustainment services according to the (Law on Licensed Engineers of Surveying and Cadastre and Offices, 2005) were transferred to private sector. LOSC are responsible for both making and controlling nonregistered services, and making registered services. These registered services are controlled by personnel at Cadastre Directorate in the responsibility region. It means that cadastral services in Turkey are performed by the collaboration of private and public sector.
Today there are 195 LOSCs situated all over the country and 5 (five) of them are in Adana (LIHHABDER, 2016).

\section{CADASTRE DIRECTORATE AND LOSCS IN ADANA}

Adana is a major city in southern Turkey. The city is situated on the Seyhan River, $35 \mathrm{~km}$ inland from the Mediterranean Sea, in south-central Anatolia. Adana lies in the heart of Çukurova, a geo-cultural region that covers the provinces of Mersin, Adana, Osmaniye and Hatay. City has 15 (fifteen) districts as Feke, Saimbeyli, Tufanbeyli, İmamoğlu, Kozan, Pozant1, Yüreğir, Ceyhan, Çukurova, Karaisalı, Sarıçam, Yumurtalık, Aladağ, Seyhan and Karataş. The City of Adana consists of the urban areas of the 4 metropolitan districts; Seyhan, Yüreğir, Çukurova, Sarıçam. Seyhan district is fully within the city limits whereas Yüreğir, Çukurova and Sarıçam districts have rural areas outside the city (Figure 1).

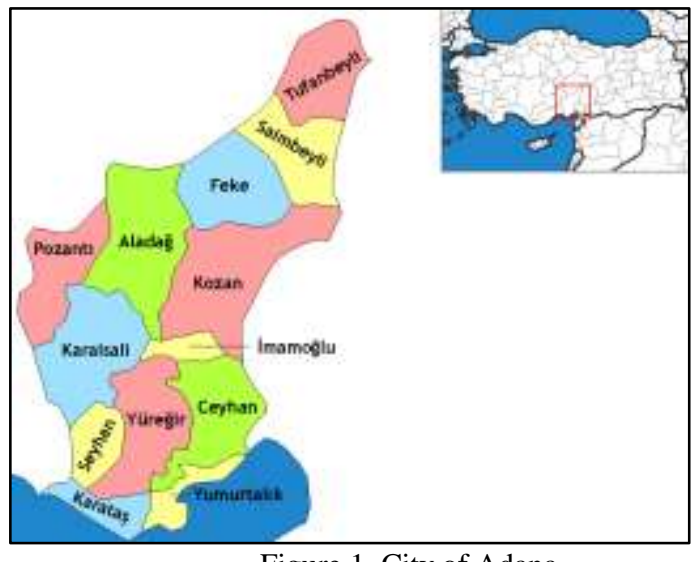

Figure 1. City of Adana.

This region is intensive in point of real estate movements and facilities. There are almost 50 (fifty) private engineers to serve on urban and rural land arrangements, land consolidation projects, expropriation projects, drinking water and sewage projects, map/plan studies subject to the registration, geographic information systems, geo-location...etc.

With regard to public works Cadastre Directorate in Adana carries out the services in city centre, and also, with its 4 (four) cadastre units in Kozan, Ceyhan, Pozantı and İmamoğlu. In the bailiwick of the Adana Cadastre Directorate, with its districts, there are 762,928 cadastral parcels as seen in Table 1. Adana Cadastre Directorate keeps going on controlling procedures on cadastre renovation studies according to $22-\mathrm{a}$ article in Cadastre Law, forest cadastre studies, digitalization of cadastral maps, expertise studies for courts, however all cadastral on-demand technical services are passed on LOSCs.

General Directorate of Land Registry and Cadastre planned 34 LOSCs totally in Adana (Table 2). Nevertheless, after the LOSC examination and preferences, 5 (five) LOSC offices were established. 1 (one) office in Çukurova District with 3 (three) capacitated districts of Aladağ, Karaisalı and Pozantı; 2 (two) offices in Sarıçam District with 6 (six) capacitated districts of Ceyhan, Feke, İmamoğlu, Kozan, Saimbeyli and Tufanbeyli; 1 (one) office in Seyhan District; 1 (one) office in Yüreğir District with 2 (two) capacitated districts of Karatas and Yumurtalı (Table 3). According to the LOSC examination result 5 (five) cadastre engineers were successful for preference to study in Adana and 5 (five) offices were established. Other 11 (eleven) districts were capacitated under these 4 (four) districts by GDLRC. 


\section{SERVICES PERFORMED BY LOSCs}

LOSCs have the responsibility of the production as "doer" and the responsibility of control works on the transactions which are not subject to the registration in the concept of cadastral technical services. These are:

- Application: to mark the borders of the real estate on the land according to the maps/plans.

- Showing the parcel: only to show the location of the real estate on the land by using the figures and measurements on maps/plans without any survey. Determination of the cadastral road boundaries is to determine the public area which are used to reach any real estate and defined as road, street and square in the plans.

The duties on the services mentioned above are given to LOSCs by the laws and regulations. Also LOSCs have made the services by the circulars and instructions of GDLRC:

- Correction of the erroneous number: to correct the wrong numbers of the offices, apartments, shops on registration plans.

- Making plans for offices, apartments, shops...etc.: These are separate sections of the buildings which have completed the construction and are ready to use.

- Making site plan: to make a scaled map showing the location of all assets in the construction field.

- Making sketches with benchmarks: a kind of application sketch to check whether the building is appropriate to its project or not.

Complementary processes have the responsibility for a fee on transportation, fees and returns to capital payments, a landregistration-plan design, construction place works to fulfil cadastral technical services which are defined by laws.

\begin{tabular}{|l|r|r|r|}
\hline $\begin{array}{c}\text { District Name } \\
\text { in Adana }\end{array}$ & $\begin{array}{c}\text { Parcel } \\
\text { number in } \\
\text { Registration } \\
\text { Office }\end{array}$ & $\begin{array}{c}\text { Parcel } \\
\text { number } \\
\text { in } \\
\text { Cadastre } \\
\text { Office }\end{array}$ & $\begin{array}{c}\text { Parsel } \\
\text { number } \\
\text { integrated } \\
\text { into } \\
\text { TAKBIS }\end{array}$ \\
\hline Feke & 50.333 & 50.603 & 50.457 \\
\hline Saimbeyli & 42.001 & 42.078 & 42.054 \\
\hline Tufanbeyli & 50.834 & 50.894 & 50.845 \\
\hline İmamoğlu & 28.896 & 29.204 & 28.919 \\
\hline Kozan & 100.156 & 100.295 & 99.989 \\
\hline Pozantı & 39.864 & 39.858 & 39.715 \\
\hline Yüreğir & 96.617 & 98.308 & 93.882 \\
\hline Ceyhan & 72.644 & 71.165 & 69.693 \\
\hline Çukurova & 27.153 & 28.153 & 25.602 \\
\hline Karaisalı & 44.656 & 43.327 & 41.933 \\
\hline Sarıçam & 68.295 & 67.962 & 63.903 \\
\hline Yumurtalık & 15.244 & 14.688 & 14.265 \\
\hline Aladă̆ & 28.010 & 26.075 & 25.774 \\
\hline Seyhan & 74.476 & 73.886 & 67.493 \\
\hline Karataş & 28.398 & 26.432 & 24.522 \\
\hline SUM & $\mathbf{7 6 7 . 5 7 7}$ & $\mathbf{7 6 2 . 9 2 8}$ & $\mathbf{7 3 9 . 0 4 6}$ \\
\hline Table 1. Pan & & & \\
\hline
\end{tabular}

Table 1. Parcel numbers in Adana. (TKGM, 2016b)

\begin{tabular}{|r|l|c|r|}
\hline $\begin{array}{c}\text { Office } \\
\text { Code }\end{array}$ & Office Place & $\begin{array}{c}\text { Office } \\
\text { number }\end{array}$ & $\begin{array}{c}\text { Average Service } \\
\text { number in last 3 } \\
\text { years }\end{array}$ \\
\hline 0101 & Aladağ & 2 & 125 \\
\hline 0102 & Ceyhan & 2 & 744 \\
\hline 0103 & Çukurova & 2 & 710 \\
\hline 0104 & Feke & 2 & 94 \\
\hline 0105 & İmamoğlu & 2 & 353 \\
\hline 0106 & Karaisalı & 2 & 198 \\
\hline 0107 & Karataş & 2 & 453 \\
\hline 0108 & Kozan & 2 & 645 \\
\hline 0109 & Pozantı & 2 & 502 \\
\hline 0110 & Saimbeyli & 2 & 82 \\
\hline 0111 & Sarıçam & 3 & 1.073 \\
\hline 0112 & Seyhan & 3 & 1.340 \\
\hline 0113 & Tufanbeyli & 2 & 123 \\
\hline 0114 & Yumurtalık & 2 & 1.705 \\
\hline 0115 & Yüreğir & 4 & \\
\hline
\end{tabular}

Table 2. LOSC numbers which are planned by GDLRC.

(TKGM, 2016b; Examination Guide, 2013.)

\begin{tabular}{|c|c|c|c|}
\hline $\begin{array}{c}\text { Opened } \\
\text { Office Place }\end{array}$ & $\begin{array}{l}\text { Opened } \\
\text { office \# }\end{array}$ & $\begin{array}{l}\text { Capacitated } \\
\text { districts }\end{array}$ & $\begin{array}{c}\text { Average } \\
\text { Service } \\
\text { number in } \\
\text { last } 3 \\
\text { years } \\
\end{array}$ \\
\hline Çukurova & 1 & $\begin{array}{l}\text { Aladağ, } \\
\text { Karaisalı, } \\
\text { Pozantı }\end{array}$ & 710 \\
\hline Sarıçam & 2 & $\begin{array}{l}\text { Ceyhan, } \\
\text { Feke, } \\
\text { İmamoğlu, } \\
\text { Kozan, } \\
\text { Saimbeyli, } \\
\text { Tufanbeyli }\end{array}$ & 1073 \\
\hline Seyhan & 1 & & 1.340 \\
\hline Yüreğir & 1 & $\begin{array}{l}\text { Karataş, } \\
\text { Yumurtalık }\end{array}$ & 1705 \\
\hline
\end{tabular}

Table 3. LOSC offices in Adana. (Approval of GDLRC, 2014)

\section{EXPERIENCES IN ADANA}

In Turkey cadastral studies are performed by Cadastral Directorates in the administration of GDLRC. Maps produced by cadastral works are used for the preparation and implementation of zoning plans, expropriation and engineering services. Also LOSCs have used these cadastral maps for their services. However they have encountered some technical problems because of the different types of cadastral maps such as maps produced according to the measurement system and maps produced according to coordinate system (Figure 2). (Caglar and Yilmaz, 2015). 


\begin{tabular}{ccc}
\multicolumn{3}{c}{ Cadastral maps according to measurement systems } \\
\hline Measuremeat Method & Number of & Percentage \\
\hline Prismatic & 49055 & 7.84 \\
\hline Graphic & 106371 & 17.05 \\
\hline Digital & 258802 & 40.29 \\
\hline Classical & 32713 & 5.02 \\
\hline Photogrammetric & 79344 & 12.98 \\
\hline Polar & 99905 & 15.45 \\
\hline Phokoplan & 627 & 0.10 \\
\hline Tachometric & 8463 & 1.27 \\
\hline Total & $\mathbf{6 3 6 1 8 0}$ & 100
\end{tabular}

Cadastral maps according to coordinate systems

\begin{tabular}{ccc}
\hline Coordinate System & Number of Sbeet & Percentage \\
\hline TrRF & 113607 & 17.86 \\
\hline French & 20 & 0.00 \\
\hline Regional & 93910 & 14.76 \\
\hline Country (ED50) & 319312 & 50.19 \\
\hline No coordinate & 109331 & 17.19 \\
\hline Total & 636180 & 100
\end{tabular}

Figure 2. Types of cadastral maps

Graphic maps (Figure 3) are not based on National Triangulation Network. They are produced as individual (independent) island sheets consisting one or more islands. The details are measured by the tachometer. On these maps the prismatic measurements are made in the villages. Graphic maps are produced according to geodetic measurement methods without any coordinate system until 1970. Sheets are made of paper and cardboard in variable dimensions. Classic measurement and drawing tools and methods are used. The point positioning accuracy is approximately \pm 2 meters. Measurement errors, adjustment errors, drawing errors and inking errors effect the result accuracy and precision (Demir and Coruh, 2007; Caglar and Yilmaz, 2015).

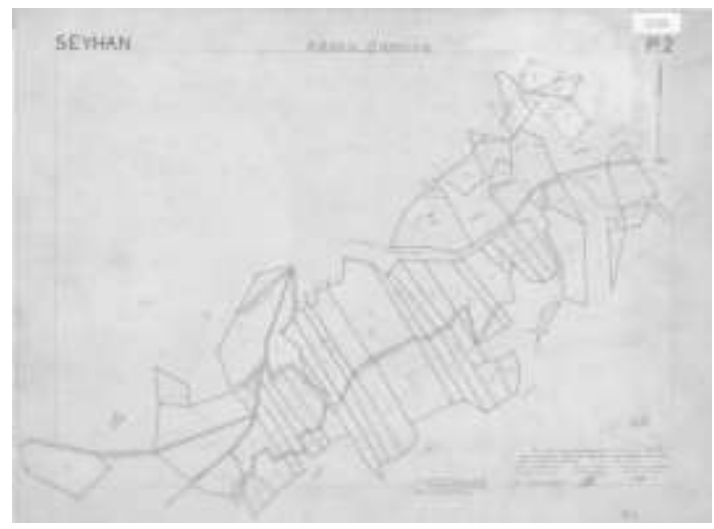

(Figure 3. Graphic map as an example.)

Polar and prismatic maps (Figure 4) are based on the triangulation network, the polygon lines are set up. Detail measurements based on polygon points are done in urban areas by using prismatic method, in rural areas the measurements are done by using tachometer. Sheets are made of cartoon, aluminium paper or astrolon. It is difficult to find ground control points on these maps. Also technical insufficiency errors on the maps and discrepancy between sheet and ground bring about problems in practice.

The other map type used in the studies is photogrammetric maps with $(50 \mathrm{~cm} * 70 \mathrm{~cm})$ astrolon sheets in European Datum 1950 (ED-50) and 3 degree Gauss-Krugger Projection (Figure 5).

The most effortless map used is digital cadastral maps (Figure 6). They are produced in national triangulation and levelling network using technology of GNSS and electronic total station.
Many of other than the digital cadastral maps are inadequate and deficient because of the technical reasons and have lost application features. The real boundaries on the ground are not shown on the maps. These errors make problems during the studies of LOSCs.

For changing land-use type, production responsibility belongs to LOSC and controlling the production belongs to Cadastre Directorate. GDLRC commands to make the processes/transactions fastly. However the controls at Cadastre Directorates take too much time even if LOSCs are quick to finish the work. So it causes the waste of time.

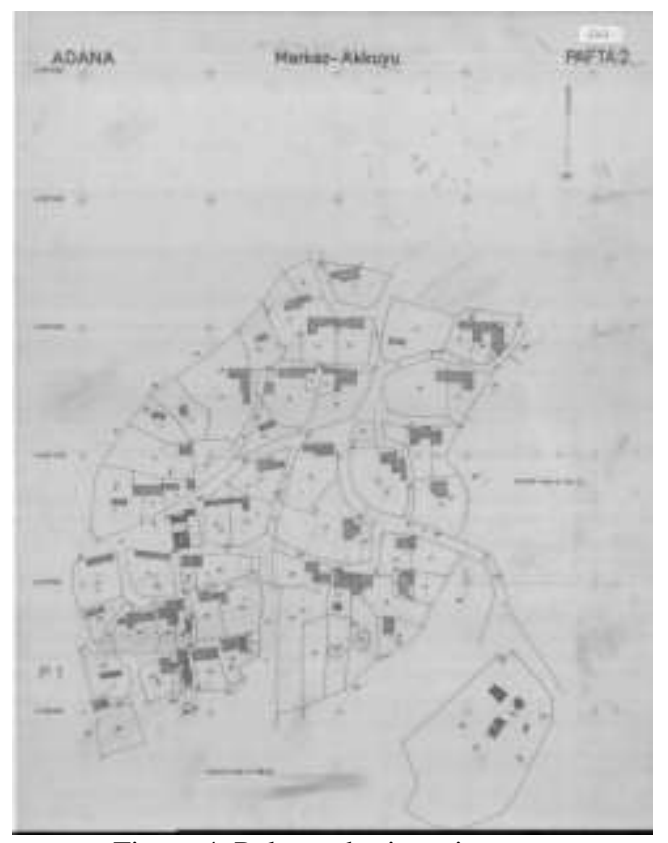

Figure 4. Polar and prismatic map as an example

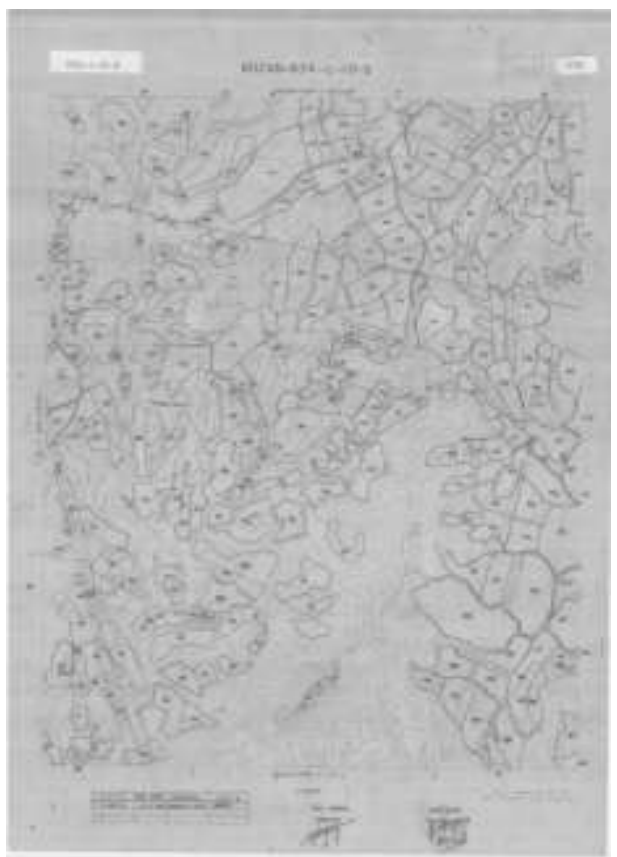

Figure 5. Photogrammetric map as an example

In application there are some problems on production authority of benchmark sketch. Benchmark sketch is basic to register a 
new building and it is the main document for change of land-use type. GDLRC directs that it is mandatory for LOSCs and Cadastre Directorates to show the location of the ownership, to apply the ownership boundaries and to prepare the sketches of these. It means that LOSCs have the authority if there is a LOSC; otherwise Cadastre Directorate has the authority. Nevertheless it is seen that the benchmark sketches are prepared by Private Surveying Offices and accepted during the control. Besides that, type change and floor ownership transactions of the real estates having the floor easement are done with benchmark sketches by Cadastre Directorates officially and free of charge.

According to the Law numbered 6306, the application and typechange transactions in the urban transformation area are done free of charge by Cadastre Directorates. It causes LOSCs to get less financial income. It makes difficult for LOSCs to survive.

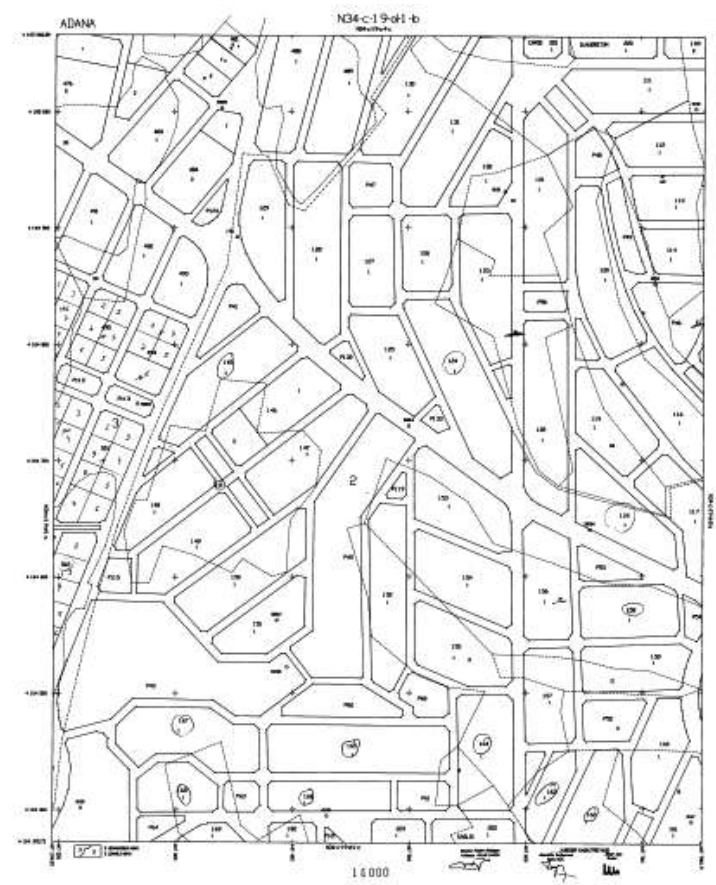

Figure 6. Digital cadastral map as an example

In the regions having more than one LOSC, LOSCs with a large burden of tax and employment have financial problems because of competitive among LOSCs and extremely price-cutting. In that situation some architectures and engineers in construction industry don't make cash payments so LOSCs are left difficult financial position.

The procedures/transactions for the application requests are realized according to "land registry example" which LOSCs want to get. "Land registry example" is not controlled whether the land registration is updated or not. It is supposed that the information on the land registry example is up-to-date in the line with the declaration of the citizens. Therefore some difficulties are experienced in case the registrations and information on these documents are not true.

\section{DISCUSSION and SOLUTION PROPOSALS}

The mandatory requirements on place, staff (personnel) and equipment for the office are determined in (Regulation on Licensed Engineers of Surveying and Cadastre and Offices, 2016). Also the places where LOSCs are to be set up are instructed in (Implementation Regulation of Law on Licensed
Engineers of Surveying and Cadastre and Offices, 2016). 2029 LOSCs are planned to be set up all over the country and the examinations are carried out after pre-study of GDLRC according to this implementing regulation. Now 195 offices are situated and nearly 1000 personnel (engineer, technician and office staff) are employed (Hopyar, 2015). The number of LOSCs in the region is determined according to the number of annual cadastral technical services however it is believed that these service numbers are not enough for the offices to survive. Geographic Information Systems (GIS) is one of the best ways to determine the number of offices considering the number of annual cadastral services, roads and neighbour districts/cities because GIS has the ability on spatial analysis. Also spatial analysis tools of GIS should be made by geomatic/surveying/cadastre engineers who have the professional formation.

LOSCs provide support for both qualified personnel training and the elimination of unemployment in surveying and cadastre sector with the employment of licensed engineer, other engineers, technicians and office staff.

The offices carry out the services with new technology more accurately, more precisely and more rapidly. Service fees and service coefficients are determined with "Decision of GDLRC" at the beginning of each year and declared. These fees contain value-added tax, income tax, technical document fee and stamp tax. They ensure large profits to State Treasury.

The basic documents of the offices are maps and registrations at Archive Unit of Cadastre Directorates. In case there is no problem on the technical documents the works go on fastly. Otherwise it is reported to Cadastre Directorate to correct them according to the related legislation. Also this allows to ensure control of the data in the technical archives and to help to eliminate errors detected. Yet it is mentioned in experiences part of this paper, different types of maps cause serious problems at works and waste of time. Although GDLRC starts the digitisation and renovation studies in the view of legislations, there are still lacks of digitized maps. Solution is to digitize all maps as soon as possible. Some problematic digitized maps should be renewed. Also necessary legal steps for coordination between offices and Cadastre Directorate are needed.

LOSCs need to believe the declaration of the citizens on land registry example. To prevent the difficulties of the wrong declaration, a special access right to TAKBIS (Information System for Land Registry and Cadastre executed by GDLRC) will be the solution of this problem.

It is seen that there is a competitive among offices. The services are public services. Therefore the competitive should be done on service quality instead of the payments.

\section{CONCLUSIONS}

Cadastral services in Turkey are public services provided by State. However some public services are transferred to LOSCs with the State's responsibility and guarantee through effective monitoring methods. This role is maintained by GDLRC. This is a kind of private-public partnership. It is intended to combine the advantages of two sides. Now State is "controller" instead of "doer" on the transactions of on-demand cadastral services.

LOSCs aim to carry out some cadastral services more effectively and fastly, and to provide employment for surveying and cadastre sector. However there are many cases on LOSCs 
about regulation articles and examinations for getting right to set up an office. Because of these cases, required legal arrangements cannot be made and the problems are encountered. It is hoped that the cases will be ended for healthy offices and services.

\section{REFERENCES}

Approval of GDLRC, 2014. Approval on LOSCs dated 03.07.2014 and numbered as 12364127-41249.

Aykıt, T., Karataş, Ş., Dursun, İ., Üzümveren, M., Hopyar Yetgin, F. and Yeğen, Z. D., 2015. WCS-CE- The World Cadastre Summit, Congress and Exhibition, "Implementation of Technical Cadastre Services Through Delegation of Authority: LİHKAB”. Istanbul, Turkey, 20-25 April 2015.

Çaglar, O. S. and Yilmaz, I., 2015. Cadastral maps used in Turkey and renewal of these maps. Electronic Journal of Map Technologies, 7(2), pp. 17-26 doi: 10.15659/hartek.15.06.66

Demir, O. and Coruhlu, Y.E., 2007. TMMOB Harita ve Kadastro Mühendisleri Odası, 11. Türkiye Harita Bilimsel ve Teknik Kurultay1, "Investigating The Solution of The Graphical Cadastre Problems: Case Syudy in Trabzon-Akcaaat". 2-6 Nisan, 2007, Ankara.

Examination Guide, 2013.Ministry of Environment and Urbanism, General Directorate of Land Registry and Cadastre, Examination Guide on Licensed Engineers of Surveying and Cadastre and Offices.

Hopyar, F., 2015. WCS-CE- The World Cadastre Summit, Congress And Exhibition, "Kadastro Teknik Hizmetlerinin Özel Sektöre Devri ve Türkiye Modeli”, Istanbul, Turkey, 20-25 April 2015.

Implementation Regulation of Law on Licensed Engineers of Surveying and Cadastre and Offices. http://www.hkmo.org.tr/mevzuat/mesleki_mevzuat.php (19.05.2016)

Konbul, Y. and Cete, M., 2015. WCS-CE- The World Cadastre Summit, Congress and Exhibition, "Role of Private Surveyors in Cadastre: The Turkish Case", Istanbul, Turkey, 20-25 April 2015.

Law on Cadastre (numbered 3402) (Official Gazette No: 19512, Date: $\quad$ 09.07.1987) www.mevzuat.gov.tr/MevzuatMetin/1.5.3402.doc $\quad(19$ May 2016).

Law on Conversion of Disaster Risk Area (numbered 6306). Official Gazette No: 28309, Date: 31.05.2012). http://www.csb.gov.tr/gm/altyapi/index.php?Sayfa=sayfa\&Tur= banner\&Id=114 (19 May 2016).

Law on Licensed Engineers of Surveying and Cadastre and Offices (numbered 5368). (Official Gazette No: 25860, Date:29.06.2005)

http://www.mevzuat.gov.tr/MevzuatMetin/1.5.5368.pdf May 2016).

LİHKABDER, 2016. Lisansl1 Harita Kadastro Mühendisleri ve Büroları Derneği, http://www.lihkabder.org.tr/?page_id=41 (14 April 2016)

Regulation on Licensed Engineers of Surveying and Cadastre. and Offices https://www.tkgm.gov.tr/tr/mevzuat/lisansli-haritakadastro-muhendisleri-ve-burolari-hakkinda-yonetmelik May 2016)

TKGM, 2016a. "TKGM İdare Faaliyet Raporu (in English: GDLRC Administration Action Report)", http://www.tkgm.agov.tr/sites/default/files/icerik/ekleri/2014_tk gm_idare_faaliyet_raporu.pdf (13 April 2016).

TKGM, 2016b. http://cbs.tkgm.gov.tr/istatistik.aspx (01 May 2016) 